\title{
PRESENCE OF THE YEAST CANDIDA TROPICALIS IN FIGS INFECTED BY THE FRUIT FLY ZAPRIONUS INDIANUS (DIP.: DROSOPHILIDAE)
}

\author{
Luiz H. Gomes ${ }^{1}$; Sergio Echeverrigaray ${ }^{2 *}$; José H. Conti ${ }^{1}$; Marcus Vinicius M. Lourenço ${ }^{1}$; Keila M.R. Duarte ${ }^{1}$ \\ 'Escola Superior de Agricultura “Luiz de Queiroz”, Universidade de São Paulo, Departamento de Genética, Piracicaba, SP, \\ Brasil. ${ }^{2}$ Instituto de Biotecnologia, Universidade de Caxias do Sul, Caxias do Sul, RS, Brasil.
}

Submitted: November 20, 2001; Returned to authors for corrections: July 18, 2002; Approved: December 15, 2002

\section{SHORT COMMUNICATION}

\begin{abstract}
In the last years, the fruit fly Zapronius indianus became the most important plague of Brazilian fig production. A fermentation process is associated with infection of the fruit by this fly. A single yeast species, Candida tropicalis, was identified in all the infected figs. The presence of one species and the low genetic variability (RAPD) of the isolates indicates an uncommonly strict interaction between C. tropicalis and Z. indianus.
\end{abstract}

Key words: Zaprionus indianus, Candida tropicalis, RAPD markers, yeast-insect association

The first register of the occurrence of Zaprionus indianus in the American continent was made in Japanese pergammon fruits in São Paulo State, Brazil. In the same region and agricultural season, these flies were observed feeding and laying eggs at the ostiole region of fig fruits in the beginning of the maturation period (14). This fly of African origin, recently introduced in Brazil, is not considered a plague in Africa. However, the loss estimates in fig production in Brazil since its appearance is around $50 \%$, becoming the most important plague of this fruit in less than two years from the first report.

The genus Zaprionus is formed by two sub-genera and 56 species (3). Z. indianus is the only species observed in tropical regions like the Comores Islands, Madagascar, Reunion Islands, Canary Islands, India, Sauddith Arabia (2), and now in Brazil. $Z$. indianus is a fly of about 2.5 to $3.0 \mathrm{~mm}$ length, with light brown body, red eyes, and characteristic longitudinal black and white stripes along the dorsal region of the head and thorax.

Most of the species of the Drosophilidae family are associated to yeast and bacteria communities. Metschnikowia hawaiiensis (6), Candida amapae, Kloeckera sp., Hanseniaspora sp., Candida guillermondii, and C. krusei (10), Candida ipomoeae (8), among several other yeast species $(1,11)$, have been isolated from drosophilids in tropical regions. It has been proposed that living yeasts represent a necessary energetic trade-off between reproductive and somatic functions in Drosophila melanogaster, increasing the fecundity of the flies, and decreasing starvation resistance and length of life (12).

The study of the microbial communities associated to the drosophilid Zaprionus indianus is especially important considering the plague status of this fruit fly in Brazil. In the present paper, we identified the yeast species associated with Zaprionus indianus in the subtropical region of São Paulo State, Brazil.

Four infested and four non infested figs were collected at four different farms at the Valinhos region, São Paulo State, Brazil, giving a total of sixteen infested and sixteen non infested fruits. The figs were opened and samples from the inner part of the fruits were plated on appropriate media.

Yeasts were isolated on YEPD $(1 \%$ yeast extract, $1 \%$ peptone, $2 \%$ glucose, and $2 \%$ agar) medium with $100 \mathrm{mg} / \mathrm{l}$ of ampicilin, 25 $\mathrm{mg} / \mathrm{l}$ of tetracycline and $100 \mathrm{mg} / \mathrm{l}$ of kanamycin. Bacteria were isolated on YEPD medium with $100 \mathrm{mg} / \mathrm{l}$ of nystatin. Ten yeast and bacterial colonies from each sample were isolated and purified on the above media.

\footnotetext{
* Corresponding author. Mailing Address: Instituto de Biotecnologia, Universidade de Caxias do Sul, R. Francisco Getúlio Vargas, 1130. 95001-970, Caxias do Sul, RS, Brasil. Telephone/Fax: (+5554) 218-2149. E-mail: selaguna@yahoo.com
} 
The reference yeast strains used were: IZ-300 (Candida utilis), IZ-809 (Candida tropicalis), ATCC-8655 and IZ-431 (Candida kefyr), IZ-1339 (Kluyveromyces marxianus isolated from a drosophilid), and FF (Saccharomyces cerevisiae). The fermentation or assimilation of sugars was evaluated on YNB with aminoacids (Difco) and $1 \%$ of the following sugars: maltose, arabinose, raffinose, celobiose, lactose, xylose, starch, inulin, sucrose, and melezitose.

Two isolates from of each farm were analyzed by RAPD. DNA for RAPD analysis was isolated by the SDS method (4). The amplification reactions (16) were performed in a final volume of 25 $\mu \mathrm{l}$ containing $20 \mathrm{mM}$ Tris- $\mathrm{HCl} \mathrm{pH} 8.0,50 \mathrm{mM} \mathrm{KCl}, 3.75 \mathrm{mMMgCl}_{2}$, $100 \mu \mathrm{MdNTPs}$ (Gibco-BRL), 5 pmol primer(10bp), 40 ng of genomic DNA and 1.5 units of Taq DNA polymerase (Gibco-BRL). Amplification was performed in a thermal cycler PTC-100 (MI Research Inc.) programmed for 40 cycles of $1 \mathrm{~min}$ at $92^{\circ} \mathrm{C}, 1 \mathrm{~min}$ at $37^{\circ} \mathrm{C}$ and $2 \mathrm{~min}$ at $72^{\circ} \mathrm{C}$, with a final extension of $3 \mathrm{~min}$ at $72^{\circ} \mathrm{C}$. The amplification products were separated by electrophoresis in $1.4 \%$ $\mathrm{w} / \mathrm{v}$ agarose gels and visualized by staining with ethidium bromide. The following decamer primers from Operon Techn. Inc. were used for the analysis: OPB-01 (GTTTCGCTCC), OPB-10 (CTGCTGGGAC), OPB-04 (GGACTGGAGT), OPB-11 (GTAGACCCGT), OPB-12 (CCTTGACGCA), OPB-14 (TCCGCTCTGG) and OPB-17 (AGGGAACGAG). Band sharing analysis (Jaccard's coefficient) was conducted. Cluster analysis and dendrogram based on UPGMA (Unweighted Pair-Group Method with Arithmetic average) were generated to estimate using NTSYS-pc. To evaluate the reproducibility of the branching patterns, bootstrap probabilities were calculated using 1000 bootstrap resampling data with the program WinBoot.

Yeasts and bacteria were present in high concentrations in all figs infested with Zaprionus, and no yeast was found in healthy fruits. Flies obtained from surface-sterilized pupa harbored both yeast and bacteria. However, no yeast or bacteria were isolated from larvae obtained from surface-sterilized eggs. The association of yeast and bacteria to insects, in particular, to drosophilids, has been reported in several opportunities $(1,6,7,8,10,11)$. These microorganisms are part of the diet of these flies, and can interfere with their development (12).

All the bacteria isolated were characterized as Gram positive, rod-shaped, spore forming, motile bacterium of the genus Bacillus. Further characterization of these bacteria is in process.

All the yeast colonies were cream-colored, with similar morphology. Fifteen of the colonies isolated from infected figs were characterized. All isolates were imperfect budding yeasts, able to grow at $37^{\circ} \mathrm{C}$. Yeast cells, grown in YEPD liquid medium at $30^{\circ} \mathrm{C}$ for 3 days, were ovoid in shape with well visible vacuolar structures.

Ten isolates were further characterized for their ability to assimilate different carbon sources, and to grow on YEPD media supplemented with cyclohexamide. The results were identical for all isolates and they were classified as Candida tropicalis (5).

The RAPD pattern of Candida tropicalis isolates was compared to those of reference strains. As can be observed in Fig. 1, the pattern obtained for one of the isolates is almost identical to that of the reference strain IZ-809 (C. tropicalis), and different from the patterns obtained for the other species. This similarity with the reference strain was also obtained with the other primers and isolates. RAPD markers have been used with success for the identification and characterization of clinical isolates of several species of Candida $(9,13)$.

Several Candida species, such as C. lipophila, $C$. drosophilae, $C$. restingae, $C$. sonorensis, $C$. deserticola, $C$. guillermondii and C. krusei have been isolated from Drosophila spp. and other insects $(1,5,10,11)$. Candida tropicalis, as well as other species of Candida, Hanseniospora, Hansenula, Trichosporon, Rhodotorula, Cryptococcus and Aureobasidium have been isolated from the gut of adult Cotinis nitida beetles (15). In general, more than one yeast species is associated to each insect, and yeasts communities are significantly influenced by the habitat rather than phylogeny of the flies $(7,11)$.

The multivariate analysis of RAPD data (Fig. 2) of eight yeasts isolated from different infected figs confirmed that all of them belonged to the same species. The eight isolates clustered together with the reference strain IZ-809. The variation observed among the isolates was very low when compared to that obtained with perfect yeast species, but is within the range previously observed for $C$. tropicalis and other imperfect yeasts of the genus Candida isolated from clinical samples $(9,13)$.

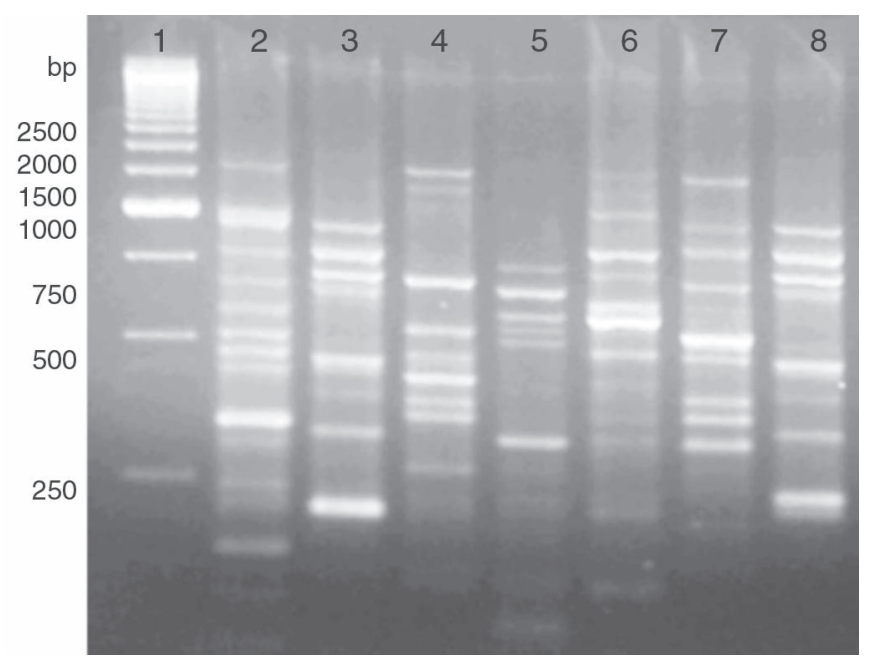

Figure 1. RAPD patterns of six yeast, isolated from figs infected with Zaprionus indianus, using primer OPB17. Lines from left to right: 1- DNA ladder, 2- IZ-300 (Candida utilis), 3- IZ-809 (Candida tropicalis), 4- ATCC-8655 (Candida pseudotropicalis), 5- IZ-1339 (Kluyveromyces marxianus isolated from a drosophilid), 6- FF (Saccharomyces cerevisiae), 7- IZ-431 (Candida kefyr), 8- A3 (Yeast isolated from Z. indianus). 


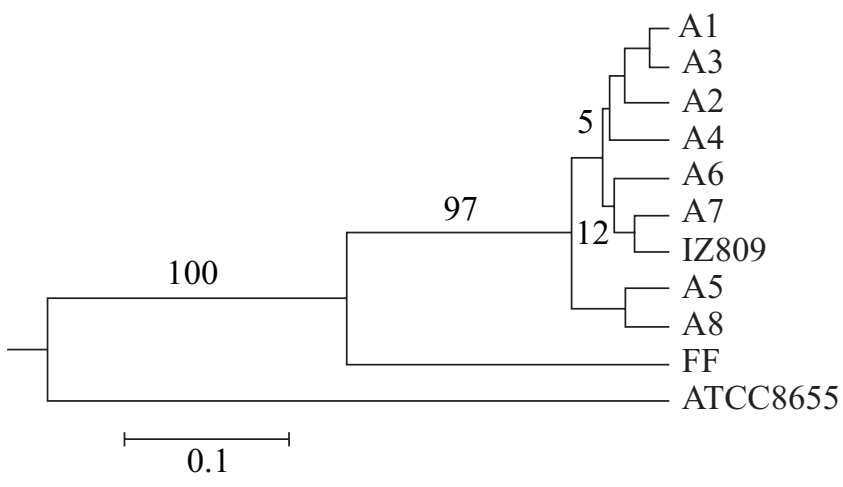

Figure 2. Dendrogram based on UPGMA analysis of the phenetic similarity (Jaccard's coefficient) of eight isolates (A1 - A8) obtained from infected figs and reference strains $C$. tropicalis (IZ 809), C. kefyr (ATCC 8655) and Saccharomyces cerevisiae $(\mathrm{FF})$, as determined by 64 RAPD markers using seven decameric primers. Numbers above internal branches are bootstrap probabilities (\%) based on 1000 bootstrap resampling.

The presence of only one yeast species and the high genetic uniformity observed among the isolates suggest an uncommonly and so far unreported strict yeast-insect interaction between C. tropicalis and Zaprionus indianus. We are currently working on the further characterization of this association, and the classification of bacterial isolates.

\section{RESUMO}

\section{Presença da levedura Candida tropicalis em figos infestados pela mosca da fruta Zaprionus indianus (Dip.: Drosophilidae)}

Nos últimos anos, a mosca-africana-do-figo Zaprionus indianus tem se tornado a praga mais importante desta cultura no Brasil. Um processo fermentativo está associado com a infecção dos frutos por esta mosca. Uma única espécie de levedura, Candida tropicalis, foi identificada nos figos infectados. A presença de uma única espécie de levedura e a baixa variabilidade genética (RAPD) dos isolados indica uma relação muito estreita entre $C$. tropicalis e $Z$. indianus.

Palavras-chave: Zaprionus indianus, Candida tropicalis, marcadores de RAPD, associação inseto-levedura.

\section{REFERENCES}

1. Braga, A.A.; Benevides de Morais, P.; Linardi, V.R. Screening of yeasts form Brazilian Amazon Rain Forest for extracellular protainases production. Syst. Appl. Microbiol., 21: 353-359, 1998.

2. Chassagnard, M.T.; Kraaijeveld, A.R. The occurrence of Zaprionus sensu stricto in the Paleoartic Region (Diptera: Drosphilidae). Ann. Soc. Entomol. Fr., 27: 495-496, 1991.

3. Chassagnard, M.T.; Tsacas, L. Le sous-genre Zaprionus S. Str. définition de groupes d'espèces et révision du sous-groupe vittiger (Diptera: Drosophilidae). Ann. Soc. Entomol. Fr., 29: 173-194, 1993.

4. Johnston, J.R. Yeast: a practical approach. IRL Press, Oxford, 1988, p. $107-122$

5. Kurtzman, C.P.; Fell, J.W. The Yeasts: A Taxonomic Study. $4^{\text {th }}$ Edn. Elsevier Sci. Publ., Amasterdam, 1998, 1055p.

6. Lachance, M.A.; Starmer, W.T.; Phaff, H.J. Metschnikowia hawaiiensis sp. nov., a heterothallic haploid yeast from Hawaiian morning glory and associated drosophilids. Int. J. Syst. Bact., 40: 415-420, 1990.

7. Lachance, M.A.; Gilbert, D.G.; Starmer, W.T. Yeast communities associated with Drosophila species and related flies in an eastern oak-pine forest: a comparison with western communities. J. Ind. Microbiol., 14: 484-494, 1995.

8. Lachance, M.A.; Rosa, C.A.; Starmer, W.T.; Bowles, J.M. Candida ipomoeae, a new yeast species related to large-spored Metschnikowia species. Can. J. Microbiol., 44: 718-722, 1998.

9. Lehmann, P.F.; Lin, D.; Lasker, B.A. Genetic identification and characterization of species and strains within the genus Candida by using random amplified polymorphic DNA. J. Clin. Microbiol., 30: 3249-3254, 1992

10. Morais, P.B.; Martins, M.B.; Klaczko, L.B.; Mendonca-Hagler, L.C.; Hagler, A.N. Yeast succession in the Amazon fruit Parahancornia amapa as resource partitioning among Drosophila spp. Appl. Environ. Microb., 61: 4251-4257, 1995.

11. Rosa, C.A.; Lachance, M.A.; Starmer, W.T.; Barker, J.S.; Bowles, J.M.; Schlag, E.B. Kodamaea nitidulidarum, Candida restingae and Kodamaea anthophila, three new related yeast species from ephemeral flowers. Int. J. Syst. Bacteriol., 49: 309-318, 1999.

12. Simmons, F.H.; Bradley, T.J. An analysis of resource allocation in response to dietary yeast in Drosphila melanogaster. J. Insect Physiol., 43: 779-788, 1997

13. Thanos, M.; Schönian, G.; Meyer, W.; Schweynoch, C.; Gräser, Y.; Mitchell, T.G.; Presber, W.; Tietz, H.J. Rapid identification of Candida species by DNA fingerprinting with PCR. J. Clin. Microbiol., 34: 615-621, 1996

14. Vilela, C.R. Mosca-africana-do-figo, Zaprionus indianus (Diptera: Drosophilidae). In: Vilela, E.F.; Zucchi, R.A.; Cantor, F. (eds.) Histórico e impacto pragas introduzidas no Brasil. Editora Holos, SP., 2000, p. 48-52.

15. Vishniac, H.S.; Johnson, D.T. Development of a yeast flora in the asult green June beetle (Cotinis nitida, Scarabaeidae). Mycologia, 82: 471-479, 1990

16. Williams, J.G.K.; Rubelik, A.R.; Livak, K.L.; Rafalski, J.A.; Tingey, S.V. DNA polymorphisms amplified by arbitrary primers are useful as genetic markers. Nucleic Acid Res., 18: 6531-6535, 1990. 